\title{
Effect of Organizational Learning on the Hard Skills, Soft Skills and Innovation of Employees: Evidence from Information Technology Industries
}

\author{
Evalina $^{1}$, Rahayu Tri Utami ${ }^{2}$, Darmawan ${ }^{3}$, Denok Sunarsi ${ }^{4}$, VIp Paramarta ${ }^{5}$, Udi Iswadi ${ }^{6}$, Bakri $^{7}$, R \\ Dewi Mutia Farida ${ }^{8}$ \\ 1.2.3Politeknik LP3I Jakarta, Indonesia \\ ${ }^{4}$ Universitas Pamulang, Tangerang Selatan, Banten, Indonesia \\ ${ }^{5}$ Universitas Sangga Buana, Bandung, Jawa Barat, Indonesia \\ ${ }^{6}$ Universitas Al-Khairiyah, Cilegon, Banten, Indonesia \\ ${ }^{7}$ Ministry of Religion, Tangerang Regency, Banten, Indonesia \\ ${ }^{8}$ Politeknik PGRI Banten, Indonesia \\ Coresponding Email: eva_lina@plj.ac.id
}

\begin{abstract}
This study aims to measure the influence of organizational learning on the improvement of hard skills, soft skills and teacher innovation capability in Indonesia.Hard skills and soft skills as mediated variables. Data collection was carried out by simple random sampling via electronic to a population of information technology industries . The returned and valid questionnaire results were 223 samples. Data processing using SEM method with SmartPLS 3.0 software. The results of this study are organizational learning has a positive and significant effect on employee innovation capability, both directly and through mediating hard skills and soft skills.
\end{abstract}

Keywords: Hard skills, education 4.0, organizational learning, soft skills, teacher innovation capability

\section{INTRODUCTION}

In the current industrial 4.0 era, marked by increasingly fierce competition, sustainability remains an important concern and issue. Teacher innovation capability is a driver of business sustainability. This performance depends on the knowledge culture that is embedded in the organization. Knowledge consisting of tacit and hard skills. Many researchers discuss teacher innovation capability, which concludes that innovation is influenced by leadership (Samsir, 2018; Schuckert et al, 2018; Villaluz \& Hechanova, 2019), employee involvement climate (Naqshbandi, Tabche \& Choudhary, 2019) knowledge sharing (Kim \& Shim, 2018) knowledge search (Wang, Chen \& Chang, 2019) collaborative culture (Yang, Nguyen \& Le, 2018) and knowledge process (Imran et al, 2018). This study aims to examine the effect of hard skills and soft skills on teacher innovation capability of employees in corporate educational institutions in the context of welcoming industrial revolution 4.0. Previous researchers have proven the positive and significant effect of hard skills and soft skills on teacher innovation capability (Ganguly et al, 2019; Aulawi, 2018; Rumanti et al, 2018 \& 2019; Torres \& Liang, 2016; Li et al, 2019). More specifically, many researchers conclude that soft skills have a positive and significant effect on teacher innovation capability (Perez-Luno et al, 2018), all of which are within the scope of business organizations. However, there are researchers who say that formal \& informal learning affects the teacher innovation capability of employees in the company (Lecat, Beausaert, \& Raemdonck, 2018).

Hard skills are one type of knowledge that is easily documented and shaped (Choi \& Lee, 2003; Sousa \& Rocha, 2019; Borrego et al, 2019; Wokcik et al, 2019; Cifariello, Ferragina \& Ponza, 2019; Che et al, 2018; Tang et al, 2016; Bashir \& Farooq, 2019; Attia \& Salama, 2018), are easy to articulate (Haamann \& Basten, 2018) and are usually knowledge inherent in the Company (Afsar, Masood \& Umrani, 2019). In addition, hard skills can be created, written and transferred between the Company's activity units (Lombardi, 
2019). Transfer of hard skills between employees is more easily driven by a mechanism and a conducive Company culture. Hard skills can be described in general terms and are also based on the specific context in which these skills are used. Rainsbury et al. (2002) defines hard skills, skills related to technical aspects to perform multiple tasks in a job. Therefore, hard skills are basically cognitive and influenced by intellectual quotient (IQ) (Muhammad et al, 2019; Kenayathulla, Ahmad \& Idris, 2019; Tsotsotso et al, 2017; Fan, Wei \& Zhang, 2017). Contextually, several researchers use the concept of hard skills in particular state management. Azim et al. (2010) generally refer to hard skills in the context of project management as processes, procedures, tools, and techniques (Gale et al, 2017; Laker \& Powell, 2011)

Knowledge is classified into two types including: soft skills and hard skills (Polanyi, 1966). The definition of soft skills is knowledge that still exists in human minds and is very personal (Chen et al, 2018; Holford, 2018; Khoshoror \& Gilaninia, 2018; Zebal, Ferdous \& Chambers, 2019; Agyemang \& Boateng, 2019; Perez-Fuillerat et al, 2018), it is difficult to define and divide naturally (Deranek, McLeod \& Schmidt, 2017; Wang \& Liu, 2019; Asher \& Popper, 2019) so that the transformation requires personal interaction (Lee, 2019). These soft skills are rooted in a person's actions and experiences, including idealism, values, and emotions (Boske \& Osanloo, 2015; Kawamura, 2016; Hartley, 2018). Good organizational learning will be more resilient to crises (Starbuck, 2017). Dimensions such as desire, discipline, decision making, and parity are presented as important elements of organizational learning (Wetzel \& Tint, 2019; Urban \& Gaffurini, 2018). Organizational learning is also an important performance indicator for evaluating overall organizational performance (Qi \& Chau, 2018) which is able to help build the necessary knowledge resources and maintain company growth and sustainability.

\section{METHOD}

The method used in this study is a quantitative method. Data collection was carried out by distributing a questionnaire to 223 repondents of employees. The population in this study were employees of IT Industries whose numbers have not been identified with certainty. The questionnaire was distributed electronically using simple random sampling technique. 223 respondents.

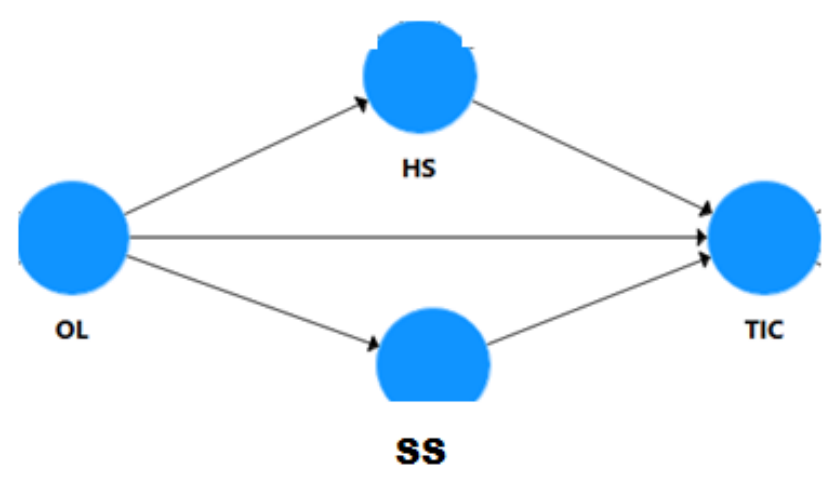

Fig 1. Research Model

$\mathrm{H} 1$ : Organizational learning has a direct effect on teacher innovation capability

$\mathrm{H} 2$ : Organizational learning has a direct effect on hard skills

H3: Organizational learning has a direct effect on soft skills

H4: Hard skills have a direct effect on teacher innovation capability

H5: Soft skills have a direct effect on teacher innovation capability

H6: Organizational learning has an indirect effect on innovation capability through mediating hard skills

H7: Organizational learning has an indirect effect on innovation capability through mediating soft skills

\section{RESULTSAND DISCUSSION}

The testing phase of the measurement model includes testing for convergent validity, discriminant validity and composite reliability. The results of the PLS analysis can be used to test the research hypothesis if all indicators in the PLS model have met the requirements of convergent validity, discriminant validity and reliability tests. Convergent validity tests are carried out by looking at the loading factor value of each indicator on the construct. In most references, a factor weight of 0.5 or more is considered to have sufficiently strong 
validation to explain latent constructs (Chin, 1998; Hair et al, 2010; Ghozali, 2014). In this study, the minimum limit for the accepted loading factor is 0.5 , provided that the AVE value of each construct is> 0.5 (Ghozali, 2014).

Based on the estimation results of the PLS model in the image above, all indicators have a loading factor value above 0.5 so that the model has met the convergent validity requirements. Apart from looking at the loading factor value of each indicator, convergent validity was also assessed from the AVE value of each construct. The AVE value for each construct of this study was above 0.5 . So the convergent validity of this research model has met the requirements. The value of loadings, cronbach's alpha, composite reliability and AVE for each complete construct can be seen in table 1 below:

Tabel 2. Items Loadings, Cronbach's Alpha, Composite Reliability, and Average Variance Extracted (AVE)

\begin{tabular}{|c|c|c|c|c|c|}
\hline Varables & Items & Loadings & $\begin{array}{c}\text { Cronbach's } \\
\text { Alpha }\end{array}$ & $\begin{array}{l}\text { Composite } \\
\text { Reliability }\end{array}$ & AVE \\
\hline \multirow{5}{*}{$\begin{array}{l}\text { Organizational Learning } \\
(\mathrm{OL})\end{array}$} & OL1 & 0.850 & 0.897 & 0.924 & 0.710 \\
\hline & OL2 & 0.880 & & & \\
\hline & OL3 & 0.882 & & & \\
\hline & OL4 & 0.819 & & & \\
\hline & OL5 & 0.778 & & & \\
\hline \multirow{6}{*}{$\begin{array}{l}\text { Hard Skills } \\
\quad \text { (HS) }\end{array}$} & HS1 & 0.643 & 0.844 & 0.884 & 0.562 \\
\hline & HS2 & 0.713 & & & \\
\hline & HS3 & 0.762 & & & \\
\hline & HS4 & 0.821 & & & \\
\hline & HS5 & 0.792 & & & \\
\hline & HS6 & 0.753 & & & \\
\hline \multirow{4}{*}{$\begin{array}{l}\text { Soft Skills } \\
\quad(S S)\end{array}$} & SS1 & 0.811 & 0.861 & 0.905 & 0.705 \\
\hline & $\mathrm{SS} 2$ & 0.855 & & & \\
\hline & SS3 & 0.816 & & & \\
\hline & SS4 & 0.877 & & & \\
\hline \multirow{5}{*}{$\begin{array}{c}\text { Teacher Innovation Capability } \\
\text { (TIC) }\end{array}$} & TIC1 & 0.806 & 0.878 & 0.911 & 0.673 \\
\hline & TIC 2 & 0.830 & & & \\
\hline & TIC 3 & 0.833 & & & \\
\hline & TIC 4 & 0.794 & & & \\
\hline & TIC 5 & 0.837 & & & \\
\hline
\end{tabular}

Discriminant validity is done to ensure that each concept of each latent variable is different from other latent variables. The model has good discriminant validity if the AVE square value of each exogenous construct the value on the diagonal) exceeds the correlation between this construct and other constructs (values below the diagonal) (Ghozali, 2014). The results of discriminant validity testing using the AVE square value, namely by looking at the Fornell-Larcker Criterion Value are obtained as follows:

Table 2. Discriminant Validity

\begin{tabular}{ccccc}
\hline Variables & $\boldsymbol{H S}$ & OL & SS & TIC \\
\hline HS & $\mathbf{0 . 7 4 9}$ & & & \\
OL & 0.711 & $\mathbf{0 . 8 4 3}$ & & \\
SS & 0.710 & 0.748 & $\mathbf{0 . 8 4 0}$ & \\
TIC & 0.736 & 0.806 & 0.720 & $\mathbf{0 . 8 2 0}$ \\
\hline
\end{tabular}


The results of the discriminant validity test in Table 3 above show that all constructs have a square root value of AVE above the correlation value with other latent constructs (through Fornell-Larcker criteria) so that it can be concluded that the model has met discriminant validity. Construct reliability can be assessed from the Cronbach's alpha value and the composite reliability of each construct. The recommended composite reliability and cronbach's alpha value is more than 0.7. (Ghozali, 2014) The results of the reliability test in Table 2 above show that all constructs have a composite reliability value and Cronbach's alpha is greater than 0.7 (> 0.7). In conclusion, all constructs have met the required reliability.

\section{Hypothesis test}

Hypothesis testing in PLS is also known as the inner model test. This test includes a significance test for direct and indirect effects as well as a measurement of the magnitude of the influence of exogenous variables on endogenous variables. To determine the effect of tacit and hard skills sharing on organizational learning and teacher innovation capability, a direct effect test is needed. The direct effect test was carried out using the t-statistical test in the partial least squared (PLS) analysis model using the SmartPLS 3.0 software. With the boothstrapping technique, the R Square value and significance test values are obtained as shown in the table below:

Table 3. Nilai $R$ Square

\begin{tabular}{ccc}
\hline & R Square & R Square Adjusted \\
\hline HS & 0.506 & 0.505 \\
SS & 0.559 & 0.559 \\
TIC & 0.712 & 0.711 \\
\hline
\end{tabular}

Table 4. Hypotheses Testing

\begin{tabular}{clccrrc}
\hline Hypotheses & Relationship & Beta & SE & T Statistics & P-Values & Decision \\
\hline H1 & OL -> TIC & 0.496 & 0.043 & 11.000 & 0.000 & Supported \\
H2 & OL ->HS & 0.711 & 0.040 & 30.326 & 0.000 & Supported \\
H3 & OL ->SS & 0.748 & 0.037 & 36.593 & 0.000 & Supported \\
H4 & HS -> TIC & 0.274 & 0.035 & 6.486 & 0.000 & Supported \\
H5 & SS -> TIC & 0.155 & 0.047 & 3.777 & 0.000 & Supported \\
H6 & OL->HS -> TIC & 0.195 & 0.029 & 6.680 & 0.000 & Supported \\
H7 & OL ->SS -> TIC & 0.116 & 0.026 & 3.684 & 0.000 & Supported \\
\hline
\end{tabular}

Based on Table 4 above, the R SquareHS value is 0.506 which means that the hard skills (HS) variable can be explained by the organizational learning (OL) variable of $50.6 \%$, while the remaining $49.4 \%$ is explained by other variables not discussed in this study. The R SquareSS value is 0.559 which means that the soft skills (SS) variable can be explained by the organizational learning (OL) variable of $55.9 \%$, while the remaining $44.1 \%$ is explained by other variables not discussed in this study. Meanwhile, the $\mathrm{R}$ value of Squareteacher innovation capability (TIC) was 0.712 , which means that the teacher innovation capability variable was able to explain organizational learning variables, hard skills and soft skills by $71.2 \%$, while the remaining $28.8 \%$ was explained by other variables not discussed in this study. Table 5 displays the T Statistics and PValues which show the influence between the research variables that have been mentioned.

\section{Discussion}

Based on the research results, it can be concluded that organizational learning has a positive and significant effect on teacher innovation capability. Either directly or through mediation of hard skills 
and soft skills. This means that the more positive the Company's organizational learning, the more individual teacher innovation capabilities of employees in the Company's educational institutions will also increase, and the employee's innovation capabilities will increase with the mediation of their hard skills and soft skills. This finding is in line with previous research on business organizations, namely Purwanto (2019), Sopa (2020), Purwanto et al (2020), Perez-Luno et al (2018), Terhorst et al (2018), Boadu et al (2018), Che et al (2019).

The results of this study also concluded that hard skills and soft skills had a positive and significant effect on employee innovation capabilities. This means that the better the hard skills and soft skills mastered by an employee, the better the innovation capabilities of employees in the Company's educational institutions. This is in line with the conclusions of Purwanto et al (2020) 's research on business organizations. This suggests that the rarest and most valuable resources in the digital era are not ordinary and mediocre employees, but employees who can create new ideas and innovations (Xu, David \& Kim, 2018). Employees who play a key role in producing and reusing their knowledge and intellectual property through education and teaching (Al-Kurdi, El-Haddadeh \& Eldabi, 2018).

Employee training in every part of the Company is a necessity with a level of intensity, content and context that is tailored to the key performance indicators of each employee. In essence, the team learning behavior created within the Company will be a driver of employee innovation (Santoso et al (2019), Santoso et al (2020), Pramono et al (2020), Prameswari et al (2020), Sihite et al (2020), Widmann \& Mulder, 2018). The process of improving skills to build teacher innovation capability of corporate education institutions should not only be limited to the company's internal processes. However, the Company's management needs to expand the process of building this innovation through efforts to absorb, articulate, utilize and manage knowledge sourced from the Company's external partners such as parents, government, society, and other educational institutions. Company management can activate learning from others when assigning employees to attend training, seminars, workshops, visits to other companies, meeting with Company committees and other strategic partners because of external knowledge, such as those from trainers, coaches, parents of students, the government, community, and other educational institutions support the power of teacher innovation capability of the company's educational institutions. In addition, commitment to learning and a seriousness to be involved in managing the learning environment are things that need to be considered. Because corporate educational institutions can become organizational learning when all members of the Company's educational institutions feel that they enjoy this learning process. Learning process is a corporate culture that encourages innovation (Purwanto, Santoso \& Purwanto, 2019). The key factors for organizational learning are trust, open communication, high involvement, the presence of industrial challenges, and a creative work atmosphere. The task of the Company's management is to facilitate the fulfillment of these key factors

\section{CONCLUSION}

In order to improve teacher innovation capability, companies need to create organizational learning as a positive environment that spurs the competence and engagement of individual employees at corporate educational institutions. Companies also need to provide autonomy and breadth to share knowledge with employees. Therefore, knowledge management will actually run effectively in the Company's educational institutions if the individual performance of each employee is in good condition (Manaf et al, 2017). Researchers continue to learn about knowledge as an important company resource. It can be said that skills are good hard. skills and soft skills can significantly improve the Company's performance. Organizational learning converts individual knowledge into corporate knowledge. Based on the conclusions of this study, the management of corporate educational institutions needs to build maximum involvement of all employees to continuously improve their hard skills and soft skills. This study has several limitations. First, this study analyzes the effect of organizational 
learning, and mediation of hard skills, soft skills, on teacher innovation capability of employees. Because there may be several other variables that affect teacher innovation capability, the author highly recommends finding, exploring and analyzing it. Second, this research is conducted within the Company's educational institutions and may not be generalizable to other institutions and industries. Therefore it is highly recommended that further research on this topic be carried out in other industries.

\section{REFERENCES}

[1]. Albandea, I. and Giret, J. (2018), "The effect of soft skills on French post-secondary graduates' earnings", International Journal of Manpower, Vol. 39 No. 6, pp. 782-799. https://doi.org/10.1108/IJM-01-2017-0014

[2]. Al-Kurdi, O., El-Haddadeh, R., \& Eldabi, T. (2018). Knowledge sharing in higher education institutions: a systematic review. Journal of Enterprise Information Management, 31(2), 226-246. doi:10.1108/jeim-09-2017-0129

[3]. Asher, D., \& Popper, M. (2019). Soft skills as a multilayer phenomenon: the "onion" model. The Learning Organization. doi:10.1108/tlo06-2018-0105

[4]. Assyne N. (2019) Hard Competencies Satisfaction Levels for Software Engineers: A Unified Framework. In: Hyrynsalmi S., Suoranta M., Nguyen-Duc A., Tyrväinen P., Abrahamsson P. (eds) Software Business. ICSOB 2019. Lecture Notes in Business Information Processing, vol 370. Springer, Cham. https://doi.org/10.1007/978-3-03033742-1_27

[5]. Attia, A. and Salama, I. (2018), "Knowledge management capability and supply chain management practices in the Saudi food industry", Business Process Management Journal, Vol. 24 No. 2, pp. 459-477. https://doi.org/10.1108/BPMJ-01-2017-0001

[6]. Aulawi, H. (2018). Improving Teacher innovation capability Trough Creativity and Knowledge Sharing Behavior. IOP Conference Series: Materials Science and Engineering, 434, $012242 . \quad$ doi:10.1088/1757899x/434/1/012242

[7]. Azim, S., Gale, A., Lawlor-Wright, T., Kirkham, R., Khan, A., \& Alam, M. (2010). The importance of soft skills in complex projects. International Journal of Managing
Projects in Business, 3(3), 387-401. doi:10.1108/17538371011056048

[8]. Baldé, M., Ferreira, A. and Maynard, T. (2018), "SECI driven creativity: the role of team trust and intrinsic motivation", Journal of Knowledge Management, Vol. 22 No. 8, pp. 1688-1711. https://doi.org/10.1108/JKM-062017-0241

[9]. Bani-Melhem, S., Zeffane, R. and Albaity, M. (2018), "Determinants of employees' innovative behavior", International Journal of Contemporary Hospitality Management, Vol. 30 No. 3, pp. 1601-1620. https://doi.org/10.1108/IJCHM-02-2017-0079

[10]. Bashir, M. and Farooq, R. (2019), "The synergetic effect of knowledge management and business model innovation on firm competence: A systematic review", International Journal of Innovation Science, Vol. 11 No. 3, pp. 362-387. https://doi.org/10.1108/IJIS-10-2018-0103

[11]. Boadu, F., Xie, Y., Du, Y.-F., \& DwomoFokuo, E. (2018). MNEs Subsidiary Training and Development and Firm Innovative Performance: The Moderating Effects of Tacit and Hard skills Received from Headquarters. Sustainability, $\quad 10(11), \quad 4208$. doi:10.3390/su10114208

[12]. Borges, R., Bernardi, M. and Petrin, R. (2019), "Cross-country findings on soft skills sharing: evidence from the Brazilian and Indonesian IT workers", Journal of Knowledge Management, Vol. 23 No. 4, pp. 742-762. https://doi.org/10.1108/JKM-04-2018-0234

[13]. Borrego, G., Morán, A. L., Palacio, R. R., Vizcaíno, A., \& García, F. O. (2019). Towards a reduction in architectural knowledge vaporization during agile global software development. Information and Software Technology. doi:10.1016/j.infsof.2019.04.008

[14]. Boske, C. and Osanloo, A. (2015), "Conclusion - Preparing all School Community Leaders to Live their Work", Living the Work: Promoting Social Justice and Equity Work in Schools around the World (Advances in Educational Administration, Vol. 23), Emerald Group Publishing Limited, pp. 405-426. https://doi.org/10.1108/S1479-

366020140000023032

[15]. Cairó Battistutti, O. \& Bork, D. Cogn Process (2017) $18: \quad 461$ https://doi.org/10.1007/s10339-017-0825-6

[16]. Cantwell, J. and Zaman, S. (2018), "Connecting local and global technological 
knowledge sourcing", Competitiveness Review, Vol. 28 No. 3, pp. 277-294. https://doi.org/10.1108/CR-08-2017-0044

[17]. Castela, B., Ferreira, F., Ferreira, J. and Marques, C. (2018), "Assessing the teacher innovation capability of small- and mediumsized enterprises using a non-parametric and integrative approach", Management Decision, Vol. 56 No. 6, pp. 1365-1383. https://doi.org/10.1108/MD-02-2017-0156

[18]. Chang, C. and Lin, T. (2015), "The role of organizational culture in the knowledge management process", Journal of Knowledge Management, Vol. 19 No. 3, pp. 433-455. https://doi.org/10.1108/JKM-08-2014-0353

[19]. Chang, W.-J., Liao, S.-H., \& Wu, T.-T. (2017). Relationships among organizational culture, knowledge sharing, and innovation capability: a case of the automobile industry in Taiwan. Knowledge Management Research \& Practice, 15(3), 471-490. doi:10.1057/s41275-016$0042-6$

[20]. Chatterjee, A., Pereira, A. and Sarkar, B. (2018), "Learning transfer system inventory (LTSI) and knowledge creation in organizations", The Learning Organization, Vol. 25 No. 5, pp. 305-319. https://doi.org/10.1108/TLO-06-2016-0039

[21]. Che, T., Wu, Z., Wang, Y. and Yang, R. (2019), "Impacts of knowledge sourcing on employee innovation: the moderating effect of information transparency", Journal of Knowledge Management, Vol. 23 No. 2, pp. 221-239. https://doi.org/10.1108/JKM-112017-0554

[22]. Che, T., Wu, Z., Wang, Y., \& Yang, R. (2018). Impacts of knowledge sourcing on employee innovation: the moderating effect of information transparency. Journal of Knowledge Management. doi:10.1108/jkm-112017-0554

[23]. Chen, H., Baptista Nunes, M., Ragsdell, G., \& An, X. (2018). Extrinsic and intrinsic motivation for experience grounded soft skills sharing in Chinese software organisations. Journal of Knowledge Management, 22(2), 478-498. doi:10.1108/jkm-03-2017-0101

[24]. Chin, WW. (1998). The Partial Least Squares Approach to Structural Equation Modeling. Modern Methods for Business Research, In: G. A. Marcoulides, Ed., Lawrence Erlbaum Associates Publisher, New Jersey, pp. 295-336.

[25]. Cifariello, P., Ferragina, P., \& Ponza, M. (2019). Wiser: A semantic approach for expert finding in academia based on entity linking. Information Systems, 82, 1-16. doi:10.1016/j.is.2018.12.003

[26]. Culot, G., Orzes, G., \& Sartor, M. (2019). Integration and scale in the context of Industry 4.0: the evolving shapes of manufacturing value chains. IEEE Engineering Management Review, 1-1. doi:10.1109/emr.2019.2900652

[27]. Darwish, T. K., Zeng, J., Rezaei Zadeh, M., \& Haak-Saheem, W. (2018). Organizational learning of Absorptive Capacity and Innovation: Does Leadership Matter? European Management Review. doi:10.1111/emre.12320

[28]. Deranek, K., McLeod, A., \& Schmidt, E. (2017). ERP Simulation Effects on Knowledge and Attitudes of Experienced Users. Journal of Computer Information Systems, 1-11. doi:10.1080/08874417.2017.1373610

[29]. Durana, Kral, Stehel, Lazaroiu, \& Sroka. (2019). Quality Culture of Manufacturing Enterprises: A Possible Way to Adaptation to Industry 4.0. Social Sciences, 8(4), 124. doi:10.3390/socsci8040124

[30]. Escrig-Tena, A. B., Segarra-Ciprés, M., García-Juan, B., \& Beltrán-Martín, I. (2018). The impact of hard and soft quality management and proactive behaviour in determining innovation performance. International Journal of Production Economics, $\quad 200, \quad 1-14$. doi:10.1016/j.ijpe.2018.03.011

[31]. Fan, C.S., Wei, X., and Zhang, J. (2017). Soft Skills, Hard Skills, and The Black/White Wage Gap. Wiley Online Library. 55(2):1032-1052. Doi: https://doi.org/10.1111/ecin.12406

[32]. Ferraris, A., Santoro, G. and Scuotto, V. (2018), "Dual relational embeddedness and knowledge transfer in European multinational corporations and subsidiaries", Journal of Knowledge Management, Vol. ahead-of-print No. ahead-of-print https://doi.org/10.1108/JKM-09-2017-0407

[33]. Ferreira, J., Mueller, J. and Papa, A. (2018), "Strategic knowledge management: theory, practice and future challenges", Journal of Knowledge Management, Vol. ahead-of-print No. ahead-of-print. https://doi.org/10.1108/JKM-07-2018-0461

[34]. Gale, A. J., Duffey, M. A., Park-Gates, S., \& Peek, P. F. (2017). Soft Skills versus Hard Skills: Practitioners' Perspectives on Interior Design Interns. Journal of Interior Design, 42(4), 45-63. doi:10.1111/joid.12105 
[35]. Ganguly, A., Talukdar, A. and Chatterjee, D. (2019), "Evaluating the role of social capital, soft skills sharing, knowledge quality and reciprocity in determining teacher innovation capability of an organization", Journal of Knowledge Management, Vol. 23 No. 6, pp. 1105-1135. https://doi.org/10.1108/JKM-032018-0190

[36]. Ghozali, I. Structural Equation Modeling, Metode Alternatif dengan Partial Least Square $(P L S)$, Edisi 4. Semarang: Badan Penerbit Universitas Diponegoro. 2014.

[37]. Gunasekaran, A., Subramanian, N., \& Ngai, E. (2018). Quality Management in the 21st Century Enterprises: Research pathway towards Industry 4.0. International Journal of Production Economics. doi:10.1016/j.ijpe.2018.09.005

[38]. Guo, Y., Jasovska, P., Rammal, H. and Rose, E. (2018), "Global mobility of professionals and the transfer of soft skills in multinational service firms", Journal of Knowledge Management, Vol. ahead-of-print No. aheadof-print. https://doi.org/10.1108/JKM-092017-0399

[39]. Haamann, T., \& Basten, D. (2018). The role of information technology in bridging the knowing-doing gap: an exploratory case study on knowledge application. Journal of Knowledge Management. doi:10.1108/jkm-012018-0030

[40]. Hair, J. F., Black. W. C., Babin. B. J.; and Anderson. R. E. (2010), Multivariate Data Analysis, 7th ed. New Jersey: Pearson Prentice Hall.

[41]. Hamada, T. (2019). Determinants of DecisionMakers' Attitudes toward Industry 4.0 Adaptation. Social Sciences, 8(5), 140. doi: 10.3390/socsci8050140

[42]. Hartley, J. (2018), "Ten propositions about public leadership", International Journal of Public Leadership, Vol. 14 No. 4, pp. 202-217. https://doi.org/10.1108/IJPL-09-2018-0048

[43]. Haseeb, M., Hussain, H. I., Ślusarczyk, B., \& Jermsittiparsert, K. (2019). Industry 4.0: A Solution towards Technology Challenges of Sustainable Business Performance. Social Sciences, $\quad 8(5), \quad 154$. doi:10.3390/socsci8050154

[44]. Hodgins, M. and Dadich, A. (2017), "Positive emotion in knowledge creation", Journal of Health Organization and Management, Vol. 31 No. 2, pp. 162-174. https://doi.org/10.1108/JHOM-06-2016-0108
[45]. Holford, W.D. (2018). The future of human creative knowledge work within the digital economy.

Futures. doi:10.1016/j.futures.2018.10.002

[46]. Holste, J. S., \& Fields, D. (2010). Trust and soft skills sharing and use. Journal of Knowledge Management, 14(1), 128-140. doi:10.1108/13673271011015615

[47]. Honeycutt, Jerry. (2000). Knowledge Management Strategies: Strategi Manajemen Pengetahuan. Jakarta : PT. Alex Media Komputindo.

[48]. Hong, J. (1999). Structuring for organizational learning. The Learning Organization, Vol. 6 No. 4, pp. 173-186. https://doi.org/10.1108/09696479910280631

[49]. Huang, F., Gardner, S. and Moayer, S. (2016), "Towards a framework for strategic knowledge management practice: Integrating soft and hard systems for competitive advantage", VINE Journal of Information and Knowledge Management Systems, Vol. 46 No. 4, pp. 492507. https://doi.org/10.1108/VJIKMS-082015-0049

[50]. Huesig, S. and Endres, H. (2019), "Exploring the digital innovation process: The role of functionality for the adoption of innovation management software by innovation managers", European Journal of Innovation Management, Vol. 22 No. 2, pp. 302-314. https://doi.org/10.1108/EJIM-02-2018-0051

[51]. Hussain, S. T., Lei, S., Akram, T., Haider, M. J., Hussain, S. H., \& Ali, M. (2018). Kurt Lewin's change model: A critical review of the role of leadership and employee involvement in organizational change. Journal of Innovation \&Knowledge, $\quad 3(3), \quad 123-127$. doi:10.1016/j.jik.2016.07.002

[52]. Ibrahim, R., Boerhannoeddin, A. and Bakare, K. (2017), "The effect of soft skills and training methodology on employee performance", European Journal of Training and Development, Vol. 41 No. 4, pp. 388-406. https://doi.org/10.1108/EJTD-08-2016-0066

[53]. Imran, M., Ilyas, M., Aslam, U. and Fatima, T. (2018), "Knowledge processes and firm performance: the mediating effect of employee creativity", Journal of Organizational Change Management, Vol. 31 No. 3, pp. 512-531. https://doi.org/10.1108/JOCM-10-2016-0202

[54]. Jakhar, S. K., Mangla, S. K., Luthra, S., \& Kusi-Sarpong, S. (2018). When stakeholder pressure drives the circular economy. 
Management Decision. doi:10.1108/md-092018-0990

[55]. Jaleel, S. and Verghis, A.M. (2015). Knowledge Creation in Constructivist Learning. Universal Journal of Educational Research 3(1): 8-12. doi: 10.13189/ujer.2015.030102.

[56]. Jiménez-Jiménez, D., \& Sanz-Valle, R. (2011). Innovation, organizational learning, and performance. Journal of Business Research, 64(4), 408-417. doi:10.1016/j.jbusres.2010.09.010

[57]. Jou, M. Lin, Y. and Wu, D. (2016) Effect of a blended learning environment on student critical thinking and knowledge transformation, Interactive Learning Environments, 24:6, 1131-1147, DOI: 10.1080/10494820.2014.961485

[58]. Kasim, A., Ekinci, Y., Altinay, L. and Hussain, K.(2018)Impact of market orientation, organizational learning and market conditions on small and medium-size hospitality enterprises,Journal of Hospitality Marketing \& Management,27:7,855-875,DOI: $10.1080 / 19368623.2018 .1438955$

[59]. Kawamura, K. (2016), "Kristine Marin Kawamura, $\mathrm{PhD}$ interviews Ikujiro Nonaka, PhD", Cross Cultural \& Strategic Management, Vol. 23 No. 4, pp. 613-632. https://doi.org/10.1108/CCSM-06-2014-0056

[60]. Kenayathulla, H., Ahmad, N. and Idris, A. (2019), "Gaps between competence and importance of employability skills: evidence from Malaysia", Higher Education Evaluation and Development, Vol. 13 No. 2, pp. 97-112. https://doi.org/10.1108/HEED-08-2019-0039

[61]. Khoshsorour, A., Gilaninia, S. 2018. Kuwait Chapter of the Arabian. Journal of Business and Management Review; Kuwait City 7(3): 14. doi: $10.12816 / 0048627$

[62]. Kim, N. and Shim, C. (2018). Social capital, knowledge sharing and innovation of smalland medium-sized enterprises in a tourism cluster. International Journal of Contemporary Hospitality Management, Vol. 30 No. 6, pp. 2417-2437. https://doi.org/10.1108/IJCHM07-2016-0392

[63]. Klaeijsen, A., Vermeulen, M., \& Martens, R. (2017). Teachers' Innovative Behaviour: The Importance of Basic Psychological Need Satisfaction, Intrinsic Motivation, and Occupational Self-Efficacy. Scandinavian Journal of Educational Research, 62(5), 769782. doi:10.1080/00313831.2017.1306803
[64]. Laker, D. R., \& Powell, J. L. (2011). The differences between hard and soft skills and their relative impact on training transfer. Human Resource Development Quarterly, 22(1), 111-122. doi:10.1002/hrdq.20063

[65]. Lecat, A., Beausaert, S. \& Raemdonck, I. (2018). On the Relation Between Teachers' (In)formal Learning and Innovative Working Behavior: the Mediating Role of Employability. Vocations and Learning11, 529-554. doi:10.1007/s12186-018-9199-x

[66]. Lee, J.-C., Shiue, Y.-C., \& Chen, C.-Y. (2016). Examining the impacts of organizational culture and top management support of knowledge sharing on the success of software process improvement. Computers in Human Behavior, 54, 462-474. doi:10.1016/j.chb.2015.08.030

[67]. Lee, Peter. (2019). Soft skills and UniversityIndustry Technology Transfer. Research Handbook on Intellectual Property and Technology Transfer (2019, Forthcoming); UC Davis Legal Studies Research Paper Forthcoming. $\quad$ doi: http://dx.doi.org/10.2139/ssrn.3417933

[68]. Li, M., Liu, H. and Zhou, J. (2018), "G-SECI model-based knowledge creation for CoPS innovation: the role of grey knowledge", Journal of Knowledge Management, Vol. 22 No. 4, pp. 887-911. https://doi.org/10.1108/JKM-10-2016-0458

[69]. Li, Song, Wang, \& Li. (2019). Intellectual Capital, Knowledge Sharing, and Innovation Performance: Evidence from the Chinese Construction Industry. Sustainability, 11(9), 2713. doi:10.3390/su11092713

[70]. Liebowitz, J. and Chen, Y. 2001. Developing knowledge-sharing proficiencies. Knowledge Management Review 3(6): 12-15. https://www.researchgate.net/publication/ 285908349_Developing_knowledgesharing_proficiencies_Building_a_supportive _culture_for_knowledge-sharing

[71]. Lievre, P. and Tang, J. (2015), "SECI and interorganizational and intercultural knowledge transfer: a case-study of controversies around a project of co-operation between France and China in the health sector", Journal of Knowledge Management, Vol. 19 No. 5, pp. 1069-1086. https://doi.org/10.1108/JKM-022015-0054

[72]. Lin, C.-P. (2006). To Share or Not to Share: Modeling Soft skills Sharing, Its Mediators and 
Antecedents. Journal of Business Ethics, 70(4), 411-428. doi:10.1007/s10551-006-9119-0

[73]. Lin, H., Lee, Y. (2017). A Study of The Influence of Organizational learning on Employees' Innovative Behavior and Work Engagement by A Cross-Level Examination. Eurasia Journal of Mathematics, Science and Technology Education, 13(7), 3463-3478. https://doi.org/10.12973/eurasia.2017.00738a

[74]. Lombardi, R. (2019). Knowledge transfer and organizational performance and business process: past, present and future researches. Business Process Management Journal, 25(1), 2-9. doi:10.1108/bpmj-02-2019-368

[75]. Lund, H. B., \& Karlsen, A. (2019). The importance of vocational education institutions in manufacturing regions: adding content to a broad definition of regional innovation systems. Industry and Innovation, 1-20. doi:10.1080/13662716.2019.1616534

[76]. Ma, Q., Mayfield, M. and Mayfield, J. (2018), "Keep them on-board! How organizations can develop employee embeddedness to increase employee retention", Development and Learning in Organizations, Vol. 32 No. 4, pp. 5-9. https://doi.org/10.1108/DLO-11-20170094

[77]. Malik, A. (2019). Creating competitive advantage through source basic capital strategic humanity in the industrial age 4.0. International Research Journal of Advanced Engineering and Science 4(1): 209-215. www.irjaes.com/pdf/V4N1Y18IRJAES/IRJAES-V4N1P195Y19.pdf

[78]. Manaf, H. A., Armstrong, S. J., Lawton, A., \& Harvey, W. S. (2017). Managerial Soft skills, Individual Performance, and the Moderating Role of Employee Personality. International Journal of Public Administration, 1-13. doi:10.1080/01900692.2017.1386676

[79]. Martínez-Costa, M., Jiménez-Jiménez, D., \& Dine Rabeh, H. A. (2018). The effect of organisational learning on interorganisational collaborations in innovation: an empirical study in SMEs. Knowledge Management Research \& Practice, 1-14. doi:10.1080/14778238.2018.1538601

[80]. Mohajan, Haradhan (2016): Sharing of Soft skills in Organizations: A Review. Published in: American Journal of Computer Science and Engineering, Vol. 3, No. 2 (1 July 2016): pp. 619. https://mpra.ub.unimuenchen.de/id/eprint/82958
[81]. Moustaghfir, K. and Schiuma, G. (2013), "Knowledge, learning, and innovation: research and perspectives", Journal of Knowledge Management, Vol. 17 No. 4, pp. 495-510. https://doi.org/10.1108/JKM-042013-0141

[82]. Muhammad, A., Ariyani, E.D., Sadikin, S., Sujana, D. (2019). Factor Analysis of the Companies Demands to the Polytechnic Graduates in Indonesia. Advanced Science Letters, Volume 25, Number 1, January 2019, pp.

$117-$

121(5)DOI:https://doi.org/10.1166/asl.2019.1 3199

[83]. Muñoz, C.A., Mosey, S. and Binks, M.(2015)The tacit mystery: reconciling different approaches to soft skills.Knowledge Management Research \& Practice,13:3,289298,DOI: $10.1057 / \mathrm{kmrp} .2013 .50$

[84]. Muqowim (2012). Pengembangan Soft Skills Karyawan. Yogyakarta: Pedagogia

[85]. Muscio, A., \& Ciffolilli, A. (2019). What drives the capacity to integrate Industry 4.0 technologies? Evidence from European $R \& D$ projects. Economics of Innovation and New Technology, $1-15$. doi:10.1080/10438599.2019.1597413

[86]. Muthuveloo, R., Shanmugam, N., \& Teoh, A. P. (2017). The impact of soft skills management on organizational performance: Evidence from Malaysia. Asia Pacific Management Review, 22(4), 192-201. doi:10.1016/j.apmrv.2017.07.010

[87]. Naqshbandi, M., Tabche, I. and Choudhary, N. (2019), Managing open innovation: The roles of empowering leadership and employee involvement climate, Management Decision, Vol. 57 No. 3, pp. 703-723. https://doi.org/10.1108/MD-07-2017-0660

[88]. Nonaka I., Hirose Nishihara A. (2018) Introduction to the Concepts and Frameworks of Knowledge-Creating Theory. In: Hirose Nishihara A., Matsunaga M., Nonaka I., Yokomichi K. (eds) Knowledge Creation in Community Development. Palgrave Macmillan, Cham. https://doi.org/10.1007/978-3-319-57481-3_1

[89]. Nonaka I., Toyama R. (2015) The Knowledgecreating Theory Revisited: Knowledge Creation as a Synthesizing Process. In: Edwards J.S. (eds) The Essentials of Knowledge Management. OR Essentials Series. Palgrave Macmillan, London. https://doi.org/10.1057/9781137552105_4 
[90]. Norwich, B., Koutsouris, G., Fujita, T., Ralph, T., Adlam, A. and Milton, F. (2016), "Exploring knowledge bridging and translation in lesson study using an inter-professional team", International Journal for Lesson and Learning Studies, Vol. 5 No. 3, pp. 180-195. https://doi.org/10.1108/IJLLS-02-2016-0006

[91]. Nouri, B.A., \& Ghorbani, R. (2017). The Effect of Knowledge Management on Organizational Innovation with the Mediating Role of Organizational Learning (Case Study : Agricultural Bank in Iran). Journal of Applied Economics and Business Research JAEBR, 7(3):

194-211.

https://www.semanticscholar.org/paper/The-

Effect-of-Knowledge-Management-on-

Innovation-of-Nouri-

Ghorbani/fb9eb1df37e4a47c9b3ac2bbf0bbc4f 4907b80a2

[92]. Nugroho, M. (2018), "The effects of collaborative cultures and knowledge sharing on organizational learning", Journal of Organizational Change Management, Vol. 31 No. 5, pp. 1138-1152. https://doi.org/10.1108/JOCM-10-2017-0385

[93]. Okuyama, R. (2017), "Importance of soft skills in incremental innovation: Implications from drug discovery cases", Journal of Strategy and Management, Vol. 10 No. 1, pp. 118-130. https://doi.org/10.1108/JSMA-02-2016-0016

[94]. Parida, V., Sjödin, D., \& Reim, W. (2019). Reviewing Literature on Digitalization, Business Model Innovation, and Sustainable Industry: Past Achievements and Future Promises. Sustainability, 11(2), 391. doi:10.3390/su11020391

[95]. Pérez-Fuillerat, N., Solano-Ruiz, M. C., \& Amezcua, M. (2018). Conocimiento tácito: características en la práctica enfermera. Gaceta Sanitaria. doi:10.1016/j.gaceta.2017.11.002

[96]. Pérez-Luño, A., Alegre, J., \& Valle-Cabrera, R. (2018). The role of soft skills in connecting knowledge exchange and combination with innovation. Technology Analysis \& Strategic Management, $\quad 1-13$. doi:10.1080/09537325.2018.1492712

[97]. Pérez-Luño, A., Alegre, J., \& Valle-Cabrera, R. (2018). The role of soft skills in connecting knowledge exchange and combination with innovation. Technology Analysis \& Strategic Management, $1-13$. doi:10.1080/09537325.2018.1492712
[98]. Polanyi, M. (1966). The Tacit dimension. New York: Doubleday \& Co.

[99]. Prasarnphanich, P., Janz, B. and Patel, J. (2016), "Towards a better understanding of system analysts' soft skills: A mixed method approach", Information Technology \& People, Vol. 29 No. 1, pp. 69-98. https://doi.org/10.1108/ITP-06-2014-0123

[100]. Qi, C. and Chau, P.Y.K.(2018)Will enterprise social networking systems promote knowledge management and organizational learning? An empirical study,Journal of Organizational Computing and Electronic Commerce, 28:1,3157,DOI: 10.1080/10919392.2018.1407081

[101]. Rainsbury, E., Hodges, D., Burchell, N. \& Lay, M. C. (2002). Ranking workplace competencies: Student and graduate perceptions. Asia-Pacific Journal of Cooperative Education, 3(2), 8-18. https://hdl.handle.net/10289/3219

[102]. Razmerita L., Phillips-Wren G., Jain L.C. (2016) Advances in Knowledge Management: An Overview. In: Razmerita L., Phillips-Wren G., Jain L. (eds) Innovations in Knowledge Management. Intelligent Systems Reference Library, vol 95. Springer, Berlin, Heidelberg. https://doi.org/10.1007/978-3-662-47827-1_1

[103]. Rothberg, H. and Erickson, G. (2017), "Big data systems: knowledge transfer or intelligence insights?", Journal of Knowledge Management, Vol. 21 No. 1, pp. 92-112. https://doi.org/10.1108/JKM-07-2015-0300

[104]. Ruiz-Torres, A., Cardoza, G., Kuula, M., Oliver, Y. and Rosa-Polanco, H. (2018), "Logistic services in the Caribbean region: An analysis of collaboration, innovation capabilities and process improvement", Academia Revista Latinoamericana de Administración, Vol. 31 No. 3, pp. 534-552. https://doi.org/10.1108/ARLA-03-2017-0078

[105]. Rumanti, A. A., Samadhi, T. M. A. A., Wiratmadja, I. I., \& Sunaryo, I. (2018). A systematic literature review on knowledge sharing for innovation: Empirical study approach. 5th International Conference on Industrial Engineering and Applications (ICIEA). doi:10.1109/iea.2018.8387153

[106]. Rumanti, A. A., Wiratmadja, I. I., Sunaryo, I., Ajidarma, P., \& Ari Samadhi, T. M. A. (2019). Firm Teacher innovation capability through Knowledge Sharing at Indonesian Small and Medium Industries: Impact of Tacit and Hard skills Perspective. 2019 IEEE 6th International Conference on Industrial Engineering and 
Applications

doi:10.1109/iea.2019.8714947

(ICIEA).

[107]. Samsir, S. (2018), The effect of leadership orientation on innovation and its relationship with competitive advantages of small and medium enterprises in Indonesia, International Journal of Law and Management, Vol. 60 No. 2, $\quad$ pp. 530-542. https://doi.org/10.1108/IJLMA-01-2017-0005

[108]. Santoro, G., Vrontis, D., Thrassou, A., \& Dezi, L. (2017). The Internet of Things: Building a knowledge management system for open innovation and knowledge management capacity. Technological Forecasting and Social Change. doi:10.1016/j.techfore.2017.02.034

[109]. Sasaki, Y. (2017), "A note on systems intelligence in knowledge management", The Learning Organization, Vol. 24 No. 4, pp. 236244. https://doi.org/10.1108/TLO-09-20160062

[110]. Schuckert, M., Kim, T., Paek, S. and Lee, G. (2018), "Motivate to innovate: How authentic and transformational leaders influence employees' psychological capital and service innovation behavior", International Journal of Contemporary Hospitality Management, Vol. 30 No. 2, pp. 776-796. https://doi.org/10.1108/IJCHM-05-2016-0282

[111]. Serna M., E., Bachiller S., O., \& Serna A., A. (2017). Knowledge meaning and management in requirements engineering. International Journal of Information Management, 37(3), 155-161. doi:10.1016/j.ijinfomgt.2017.01.005

[112]. Sousa, M. J., \& Rocha, Á. (2019). Strategic Knowledge Management in the Digital Age. Journal of Business Research, 94, 223-226. doi:10.1016/j.jbusres.2018.10.016

[113]. Spraggon, M. and Bodolica, V. (2017), "Collective soft skills generation through play: Integrating socially distributed cognition and transactive memory systems", Management Decision, Vol. 55 No. 1, pp. 119-135. https://doi.org/10.1108/MD-05-2015-0173

[114]. Stachová, K., Papula, J., Stacho, Z., \& Kohnová, L. (2019). External Partnerships in Employee Education and Development as the Key to Facing Industry 4.0 Challenges. Sustainability, 11(2), 345. doi:10.3390/su11020345

[115]. Stanica, S. and Peydro, J. (2016), "How does the employee cross-training lean tool affect the knowledge transfer in product development processes?", VINE Journal of Information and Knowledge Management Systems, Vol. 46 No. 3, pp. 371-385. https://doi.org/10.1108/VJIKMS-11-20150061

[116]. Starbuck, W. (2017), "Organizational learning and unlearning", The Learning Organization, Vol. 24 No. 1, pp. 30-38. https://doi.org/10.1108/TLO-11-2016-0073

[117]. Stewart, C., Schiavon, L.M. and Bellotto, M.L. (2017) Knowledge, nutrition and coaching pedagogy: a perspective from female Brazilian Olympic gymnasts, Sport, Education and Society, 22(4): 511-527, DOI: 10.1080/13573322.2015.1046428

[118]. Swierczek, A. (2019), "Manufacturer structural embeddedness and the network rent: the intervening role of relational embeddedness in the triadic supply chains", Supply Chain Management, Vol. 24 No. 3, pp. 334-354. https://doi.org/10.1108/SCM-06-2018-0232

[119]. Tang, V., Yanine, F. and Valenzuela, L. (2016), "Data, information, knowledge and intelligence: The mega-nano hypothesis and its implications in innovation", International Journal of Innovation Science, Vol. 8 No. 3, pp. 199-216. https://doi.org/10.1108/IJIS-072016-0022

[120]. Terhorst, A., Lusher, D., Bolton, D., Elsum, I., \& Wang, P. (2018). Soft skills Sharing in Open Innovation Projects. Project Management Journal, 49(4), 5-19. doi: $10.1177 / 8756972818781628$

[121]. Torres, O. J. J., \& Liang, D. (2016). Knowledge Sharing and the Teacher innovation capability of Chinese Firms: The Role of Guanxi. 2016 International Conference on Industrial Engineering, Management Science and Application (ICIMSA). doi:10.1109/icimsa.2016.7504015

[122]. Tsai, F. and Hsu, I. (2019), "The effects of social capital on knowledge heterogeneity", Management Decision, Vol. 57 No. 5, pp. 1237-1253. https://doi.org/10.1108/MD-122016-0909

[123]. Tsotsotso, K., Montshiwa, E., Tirivanhu, P., Fish, T., Sibiya, S., Mlangeni, T., Moloi, M. and Mahlangu, N. (2017), "Determinants of skills demand in a state- intervening labour market: The case of South African transport sector", Higher Education, Skills and WorkBased Learning, Vol. 7 No. 4, pp. 408-422. https://doi.org/10.1108/HESWBL-08-20170050 
[124]. Urban, B. and Gaffurini, E. (2018), "Social enterprises and organizational learning in South Africa", Journal of Entrepreneurship in Emerging Economies, Vol. 10 No. 1, pp. 117133. https://doi.org/10.1108/JEEE-02-20170010

[125]. Vijande M.L.S., Sánchez J.Á.L. (2017) The Effects of Organizational learning on Innovation and Performance in Kibs: An Empirical Examination. In: Campbell C.L. (eds) The Customer is NOT Always Right? Marketing Orientationsin a Dynamic Business World. Developments in Marketing Science: Proceedings of the Academy of Marketing Science. Springer, Cham. https://doi.org/10.1007/978-3-319-500089_227

[126]. Villaluz, V. and Hechanova, M. (2019), "Ownership and leadership in building an innovation culture", Leadership \& Organization Development Journal, Vol. 40 No. 2, pp. 138-150. https://doi.org/10.1108/LODJ-05-2018-0184

[127]. Viviers, H., Fouché, J. and Reitsma, G. (2016), "Developing soft skills (also known as pervasive skills): Usefulness of an educational game", Meditari Accountancy Research, Vol. 24 No. 3, pp. 368-389. https://doi.org/10.1108/MEDAR-07-20150045

[128]. Wang, C., Chen, M. and Chang, C. (2019), "The double-edged effect of knowledge search on innovation generations", European Journal of Innovation Management, Vol. ahead-ofprint No. ahead-of-print. https://doi.org/10.1108/EJIM-04-2018-0072

[129]. Wang, J., \& Liu, L. (2019). Study on the mechanism of customers' participation in knowledge sharing. Expert Systems, e12367. doi:10.1111/exsy.12367

[130]. Wang, X., Arnett, D. and Hou, L. (2016), "Using external knowledge to improve organizational innovativeness: understanding the knowledge leveraging process", Journal of Business \& Industrial Marketing, Vol. 31 No. 2, pp. 164-173. https://doi.org/10.1108/JBIM04-2014-0064

[131]. Wang, Z., \& Wang, N. (2012). Knowledge sharing, innovation and firm performance. Expert Systems with Applications, 39(10), 8899-8908. doi:10.1016/j.eswa.2012.02.017

[132]. Wetzel R., Tint B. (2019) Using Applied Improvisation for Organizational learning in the Red Cross Red Crescent Climate Centre.
In: Antonacopoulou E., Taylor S. (eds) Sensuous Learning for Practical Judgment in Professional Practice. Palgrave Studies in Business, Arts and Humanities. Palgrave Macmillan, Cham. https://doi.org/10.1007/978-3-319-99049-1_3

[133]. Widmann, A. and Mulder, R. (2018), "Team learning behaviours and innovative work behaviour in work teams", European Journal of Innovation Management, Vol. 21 No. 3, pp. 501-520. https://doi.org/10.1108/EJIM-122017-0194

[134]. Widoyoko, E.P. (2009). Evaluasi Program Pembelajaran Panduan Praktis bagi Pendidik dan Calon Pendidik (Yogyakarta: Pustaka

[135]. Wójcik, M., Jeziorska-Biel, P., \& Czapiewski, K. (2019). Between words: A generational discussion about farming knowledge sources. Journal of Rural Studies, 67, 130-141. doi:10.1016/j.jrurstud.2019.02.024

[136]. Xu, M., David, J. M., \& Kim, S. H. (2018). The Fourth Industrial Revolution: Opportunities and Challenges. International Journal of Financial Research, 9(2), 90. doi:10.5430/ijfr.v9n2p90

[137]. Yang, Z., Nguyen, V. and Le, P. (2018), Knowledge sharing serves as a mediator between collaborative culture and teacher innovation capability: an empirical research, Journal of Business \& Industrial Marketing, Vol. 33 No. 7, pp. 958-969. https://doi.org/10.1108/JBIM-10-2017-0245

[138]. Zambon, I., Cecchini, M., Egidi, G., Saporito, M. G., \& Colantoni, A. (2019). Revolution 4.0: Industry vs. Agriculture in a Future Development for SMEs. Processes, 7(1), 36. doi:10.3390/pr7010036

[139]. Zebal, M., Ferdous, A., \& Chambers, C. (2019). An integrated model of marketing knowledge - a soft skills perspective. Journal of Research in Marketing and Entrepreneurship. doi:10.1108/jrme-03-20180018

[140]. Zhang, C., Xiao, H., Gursoy, D. and Rao, Y.(2015).Soft skills spillover and sustainability in destination development.Journal of Sustainable Tourism.23(7):1029-1048,DOI: 10.1080/09669582.2015.1032299

[141]. Zhu, Q., Krikke, H. and Caniëls, M. (2018), Supply chain integration: value creation through managing inter-organizational learning. International Journal of Operations \& Production Management. 38(1): 211-229. https://doi.org/10.1108/IJOPM-06-2015-0372 
[142]. Zouaghi, F., Sánchez, M., \& Martínez, M. G. (2018). Did the global financial crisis impact firms' innovation performance? The role of internal and external knowledge capabilities in high and low tech industries. Technological Forecasting and Social Change. 132: 92-104. doi:10.1016/j.techfore.2018.01.011 